\title{
Richness and distribution of aquatic macrophytes in a subtropical reservoir in Sáo Paulo, Brazil
}

\author{
Riqueza e distribuição de macrófitas aquáticas em um reservatório subtropical em \\ São Paulo, Brasil
}

\section{Ana Carolina Pavão ${ }^{1}$, André Cordeiro Alves dos Santos ${ }^{1 *}$, Flávia Bottino², Roseli Frederigi Benassi ${ }^{3}$ and Maria do Carmo Calijuri ${ }^{2}$}

\author{
${ }^{1}$ Universidade Federal de São Carlos - UFSCar, Rodovia João Leme dos Santos, Km 110, \\ Bairro Itinga, CEP 18052-780, Sorocaba, SP, Brazil \\ ${ }^{2}$ Escola de Engenharia de São Carlos - EESC, Universidade de São Paulo - USP, \\ Avenida Trabalhador São Carlense, no 400, CEP 13566-590, São Carlos, SP, Brazil \\ ${ }^{3}$ Centro de Engenharia, Modelagem e Ciências Sociais Aplicadas - CECS, Universidade Federal do \\ ABC - UFABC, Avenida dos Estados, no 5001, Bloco A, $6^{\circ}$ andar, Bairro Bangu, CEP 09210-580, \\ Santo André, SP, Brazil \\ *e-mail: andrecas@ufscar.br
}

Cite as: Pavão, A.C. et al. Richness and distribution of aquatic macrophytes in a subtropical reservoir in São Paulo, Brazil. Acta Limnologica Brasiliensia, 2017, vol. 29, e10.

\begin{abstract}
Aims: to evaluate the richness, biomass and distribution of aquatic macrophytes in a subtropical reservoir in the dry and rainy seasons. Methods: this study was carried out in the Itupararanga Reservoir, an important water source in São Paulo State, undergoing a continuous process of eutrophication. Samples of macrophytes were collected at 12 sampling sites in the summer and at 9 sampling sites in the winter in the Itupararanga Reservoir using the quadrat method $\left(0.25 \mathrm{~m}^{2}\right)$. In the laboratory, the plants were washed to remove the coarse material and then were dried $\left(60{ }^{\circ} \mathrm{C}\right)$ for biomass determination $\left(\mathrm{gDW} . \mathrm{m}^{-2}\right)$. All the species in the sampling sites in both periods were identified using the specific literature. In each sampling site, the water temperature, $\mathrm{pH}$, electrical conductivity and dissolved oxygen were measured using a probe. The temporal and spatial differences were analyzed using t-test and a Cluster Analysis was performed. Results: The checklist showed sixteen species, $75 \%$ of them were emergent. From the 16 species, 15 were present in the summer and 10 in the winter. Eichhornia crassipes, Polygonum sp., and Urochloa sp. were the frequent taxa and had the highest biomass in both periods. The winter showed the highest biomass mainly due to the growth of free-floating species. The headwaters of the reservoir, the most eutrophic region, showed that the highest macrophyte richness and the sampling sites of this area were clustered in both the summer and winter. Conclusions: There was no significant spatial variation among the measured variables. E. crassipes, Salvinia sp. and Urochloa sp. showed a significant variation of biomass between two periods. Urochloa sp. is a nuisance species occurring in up to $60 \%$ of the sampling sites having implications for the whole catchment. Continuous macrophyte monitoring is important due to the increasing trophic status of this ecosystem.
\end{abstract}

Keywords: Itupararanga reservoir; biodiversity; spatio-temporal variability; floristic survey.

Resumo: Objetivo: avaliar a riqueza, biomassa e distribuição de macrófitas aquáticas no reservatório subtropical na estação seca e chuvosa. Métodos: este estudo foi realizado no reservatório Itupararanga, um importante manancial de abastecimento no estado de São Paulo e que está passando por contínuo 
processo de eutrofização. Macrófitas foram coletadas no reservatório em 12 locais de amostragem no verão e em 9 no inverno usando o método dos quadrados $\left(0,25 \mathrm{~m}^{2}\right)$. Em laboratório, as plantas foram lavadas para remoçáo do material aderido e secas em estufa $\left(60{ }^{\circ} \mathrm{C}\right)$ para determinação da biomassa $\left(\mathrm{gDM} \cdot \mathrm{m}^{-2}\right)$. Todas as espécies presentes nas estaçôes de amostragem foram identificadas usando literatura específica. Em cada local de amostragem, a temperatura da água, pH, a condutividade elétrica e o oxigênio dissolvido foram medidos usando uma sonda multiparâmetros. As diferenças espaciais e temporais dos parâmetros ambientais foram analisadas através do teste-t e uma análise de agrupamento foi aplicada. Resultados: O levantamento florístico indicou 16 espécies, das quais 15 espécies ocorreram no verão e 10 no inverno. Eichhornia crassipes, Polygonum sp., e Urochloa sp. foram os taxa mais frequentes e apresentaram os maiores valores de biomassa em ambos os períodos. A maior biomassa total foi registrada no inverno, principalmente devido ao aumento de espécies livre-flutuantes. Na cabeceira do reservatório, região mais eutrofizada, houve a maior riqueza de espécies e os locais de amostragem localizados nesta regiáo ficaram agrupados no verão e no inverno. Conclusóes: Não houve variação espacial das variáveis medidas. E. crassipes, Salvinia sp. e Urochloasp. apresentaram variação significativa da biomassa entre os dois períodos. Urochloa sp. é uma espécie exótica que ocorreu em mais de $60 \%$ dos locais de amostragem e pode causar sérias implicaçóes para a bacia como um todo. O contínuo monitoramento das macrófitas aquáticas é importante devido ao aumento do estado trófico do reservatório.

Palavras-chave: reservatório Itupararanga; biodiversidade; variabilidade espaço-temporal; levantamento florístico.

\section{Introduction}

The wide diversity of macrophytes is related to their capacity to colonize aquatic ecosystems with significantly different physical-chemical characteristics (Chambers et al., 2007). The Neotropical region comprises the highest diversity of macrophytes encompassing up to $60 \%$ of all aquatic vascular plants (Chambers et al., 2007). In this region, the main environmental driving forces related to the macrophyte diversity, abundance and occurrence of species with different life forms include $\mathrm{pH}$, alkalinity and nutrients (Kennedy et al., 2015).

The light and temperature conditions of the tropics, which are favorable to growth, support abundant macrophyte biomass production, especially in reservoirs. The stability of these ecosystems increases macrophyte development, generating microhabitats for fishes, macroinvertebrates and periphyton (Kovalenko et al., 2009; Padial et al., 2009) as well as changing the physical and chemical characteristics of the water and sediment (Joniak et al., 2007) due to the uptake of nutrients from the water column and sediments (Holmroos et al., 2015). Maintaining macrophyte biodiversity improves the functioning of the ecosystem, increases the transparency of water and supporting fish production (Bakker et al., 2012). On the other hand, excessive macrophyte production has a number of implications for the multiple uses of reservoirs, for example, damaging hydropower generation and navigation (Pieterse \& Murphy, 1993). These effects depend on the species, due to characteristics such as life form differences, the presence of propagules and generation time.
The land use of the watershed supports macrophyte colonization and biomass growth due to the runoff from agriculture areas (Choi et al., 2014) increasing the negative effects in the water quality. Itupararanga Reservoir is a subtropical ecosystem and its main land use is the agriculture ( $42 \%$ of the reservoir area; Garcia et al., 1999) and despite the presence of an environmental preservation area (25\%), the trophic status is increasing deteriorating the water quality. The eutrophication of the Itupararanga Reservoir is increasing over time and it is related to the high phosphorus and clorophyll a concentrations (CETESB, 2016). Many towns around the reservoir have no sewage treatment increasing the nutrient concentrations mainly in the dry season (Soares et al., 2008) contributing to the eutrophication and cyanobacteria bloom (CETESB, 2016). Aquatic macrophyte growth is closely related to the eutrophication causing concerns to the multiple uses of freshwater systems (Pieterse \& Murphy, 1993). However few studies described this community in the Itupararanga Reservoir. Due to its geographical position in a channel of reservoirs, the water quality of the Itupararanga Reservoir may influence an important aquatic system in São Paulo State by acting as a source of nuisance species.

Understanding macrophyte dynamics in reservoirs contributes to establishing biodiversity patterns and to managing this community (Martins et al., 2008; Pitelli et al., 2008; Ziegler et al., 2015). It is particularly relevant in the State of São Paulo due to the high number of reservoirs in the region, especially along the Tietê River, an important river that crosses the state and has six 
cascade reservoirs along its middle course. The main aim of this study was to evaluate the richness, biomass and distribution of aquatic macrophytes in the first upstream reservoir of the cascade reservoir system of the Tietê River watershed (Itupararanga Reservoir) in the dry and rainy seasons (winter and summer, respectively). It was hypothesized that the rainy period influences species richness and biomass since this period supports the plants growth, due to higher temperatures and nutrient intake, and also the high flow of river may carry propagules to the reservoir.

\section{Material and Methods}

\subsection{Study area}

The Itupararanga Reservoir (2336'42"S; $\left.47^{\circ} 23^{\prime} 48^{\prime \prime} \mathrm{W}\right)$ is located in the Sorocaba River Basin in the State of São Paulo (Figure 1). The reservoir is $26 \mathrm{~km}$ long and has a drainage area of $936 \mathrm{~km}^{2}$. The annual mean temperature in the watershed is $20{ }^{\circ} \mathrm{C}$ and rainy and dry months are January and August, respectively. The historical minimum temperature in the rainy month is $19{ }^{\circ} \mathrm{C}$ and the maximum is $28{ }^{\circ} \mathrm{C}$. In the dry months, the minimum and maximum historical temperatures are $14^{\circ} \mathrm{C}$ and $26^{\circ} \mathrm{C}$, respectively. The mean annual rainfall is $1231 \mathrm{~mm}$.
Itupararanga is a multipurpose reservoir used mainly to supply water to an important region of Sáo Paulo State ( $\approx 1$ million of people) and for power generation, irrigation and leisure. The trophic level of the reservoir has increased from oligotrophic to eutrophic due mainly to land use and high biological oxygen demand (BOD) (CETESB, 2012; Beghelli et al., 2014). In the headwater of the reservoir, the concentrations of chlorophyll and phosphorus are higher than other regions of this system increasing its trophic status (Cunha \& Calijuri, 2011a).

\subsection{Sampling and plant identification}

The sampling sites were selected according to the aquatic macrophyte occurrence on a visit to the entire coastal area of the Itupararanga Reservoir. In the summer (rainy season - February, 2010), 12 sampling sites were reported as having macrophytes (Figure 1). In the winter (dry season - June, 2010), the plants were found in 9 sampling sites (except in P6, P7 and P9).

Macrophyte samples were collected using the quadrat method (four replicates by collecting area and quadrat area: $0.25 \mathrm{~m}^{2}$ ) (Westlake, 1965). In the laboratory, the macrophytes were washed to remove the coarse material, separated by species and dried $\left(60^{\circ} \mathrm{C}\right)$ to a constant weight

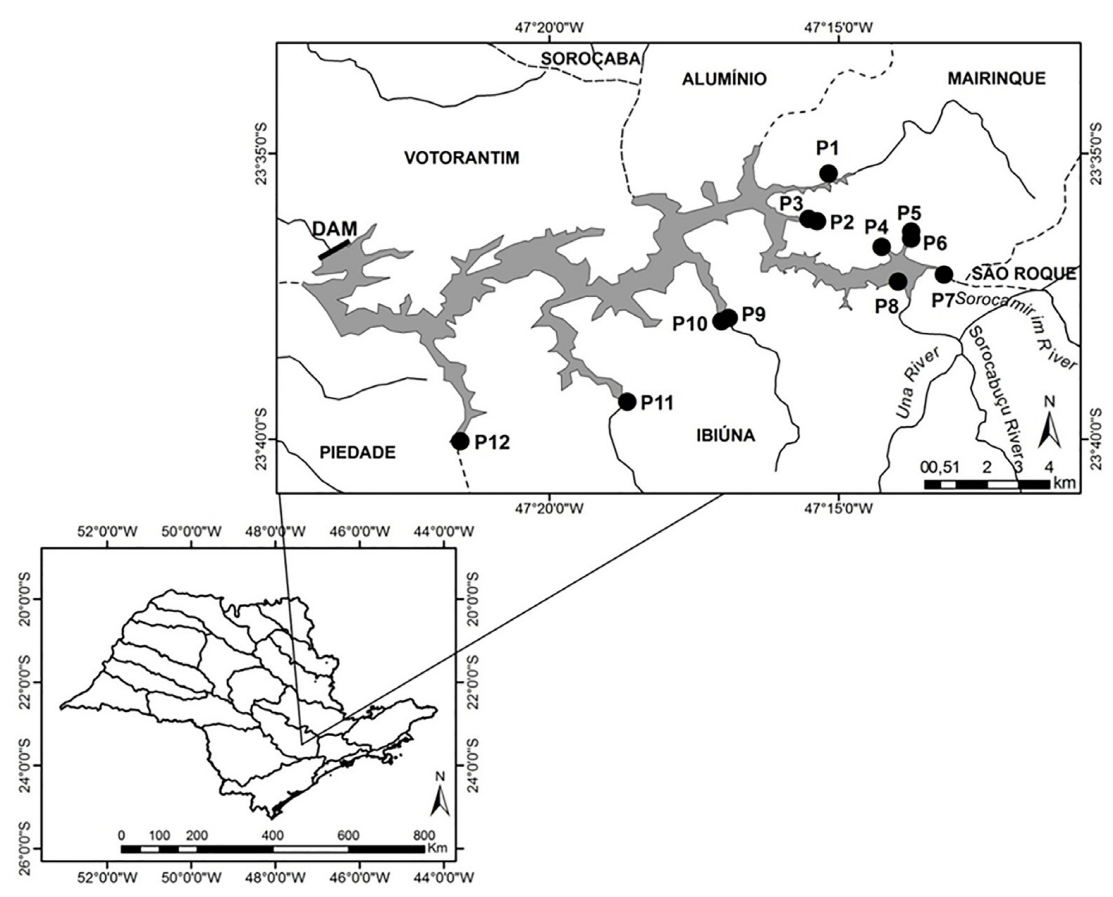

Figure 1. Location of Itupararanga Reservoir in Sorocaba watershed (São Paulo State) with sampling sites represented by black circles. 
(Pompêo \& Moschini-Carlos, 2003) to obtain the dried biomass (g DW. $\mathrm{m}^{-2}$ ). Macrophyte species identification was performed using specific literature (Amaral et al., 2008; Pott \& Pott, 2000; Scremin-Dias, 1999) and by consulting specialists from the Laboratório de Limnologia do Instituto de Biologia from the Universidade of São Paulo (USP) (Limnology Laboratory at the Institute of Biology of the University of São Paulo) and from the Instituto de Biologia, Universidade Estadual de Campinas (UNICAMP) (Institute of Biology of the University of Campinas). Species nomenclature was obtained from the REFLORA virtual herbarium (Instituto de Pesquisas Jardim Botânico do Rio de Janeiro, 2016).

The water temperature, $\mathrm{pH}$, electrical conductivity and concentrations of dissolved oxygen (DO) were measured in the sampling sites using a probe (YSI, 556). The rainfall and water flow data of the reservoir during the sampling period was provided by the dam operator.

\subsection{Data analysis}

Similarity analysis was carried out at each sampling site using the presence and absence matrix. Cluster Analysis was also carried out using the Sorensen Similarity Index and the UPGMA method (Valentin, 2000). To test the differences between the macrophyte biomass in the two different seasons, the t-test was used (significance level: 0.05) using $\mathrm{R}$ software version 2.11.1.

\section{Results}

The highest rainfall and outflow occurred in the summer (January: $504 \mathrm{~mm}$ and $37 \mathrm{~m}^{3} \cdot \mathrm{s}^{-1}$, respectively). In February, the rainfall and outflow values were $110 \mathrm{~mm}$ and $33 \mathrm{~m}^{3} \cdot \mathrm{s}^{-1}$, respectively. In the winter (June), the rainfall was $37 \mathrm{~mm}$ and the outflow was $13 \mathrm{~m}^{3} \cdot \mathrm{s}^{-1}$ (Figure 2A). The mean water level showed a low variation between the sampling periods (maximum in the summer: $825.4 \mathrm{~m}$; maximum in the winter: $823.5 \mathrm{~m}$ in the winter) (Figure 2B).

The physical and chemical variables showed no spatial variation. It is important to highlight the highest values of electrical conductivity in the sampling sites next to the reservoir headwater (P2, P3 and P4) from 61 to $73 \mu \mathrm{S} . \mathrm{cm}^{-1}$ (Figure 3) showing that these sites were significantly different from others $(\mathrm{p}=0.03$ for $\mathrm{P} 2$ and $\mathrm{P} 3$ and $\mathrm{p}=0.024$ for $\mathrm{P} 4)$, except for P11 and P12. In winter, the concentration of dissolved oxygen was low in the P2 and P3 (5.2 mg. $\mathrm{L}^{-1}$ in both sampling sites). Considering the temporal variation, the temperature was significantly higher in the summer $(\mathrm{p}=0.038)$ and dissolved oxygen showed no significant variation between the two seasons $(\mathrm{p}=0.05)$.
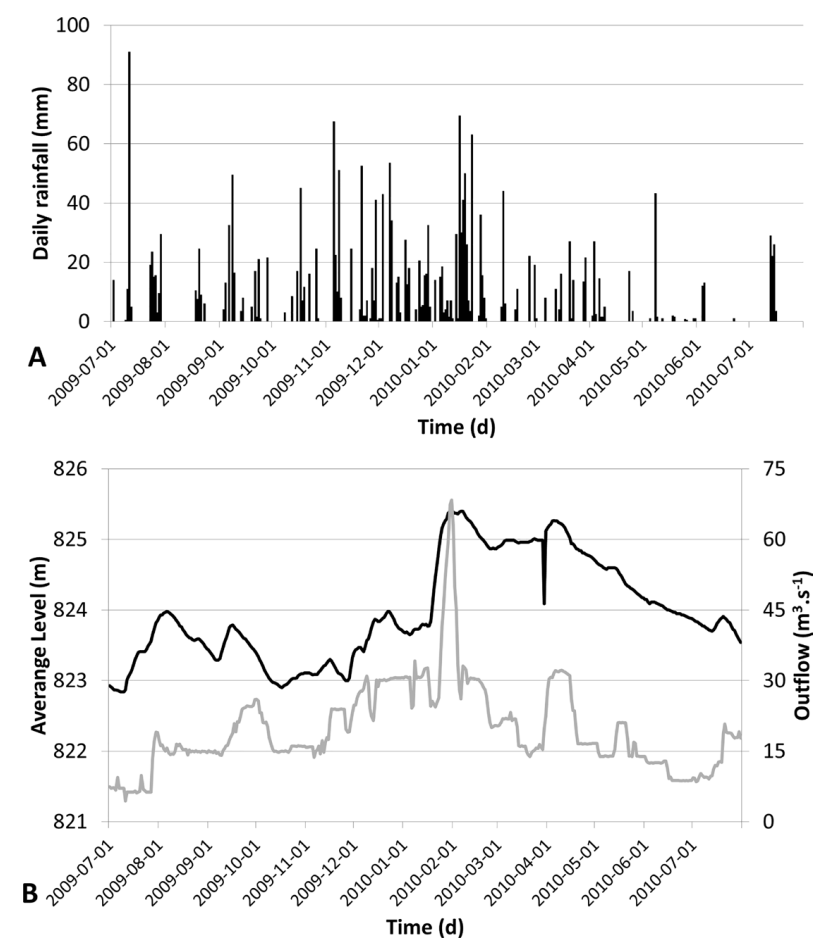

Figure 2. Climatological data of the Itupararanga Reservoir from June, 2009 to June, 2010. (A) Daily rainfall; (B) Water level (black line) and outflow (diffluent flow - gray line) Source: Votorantim Energia. 

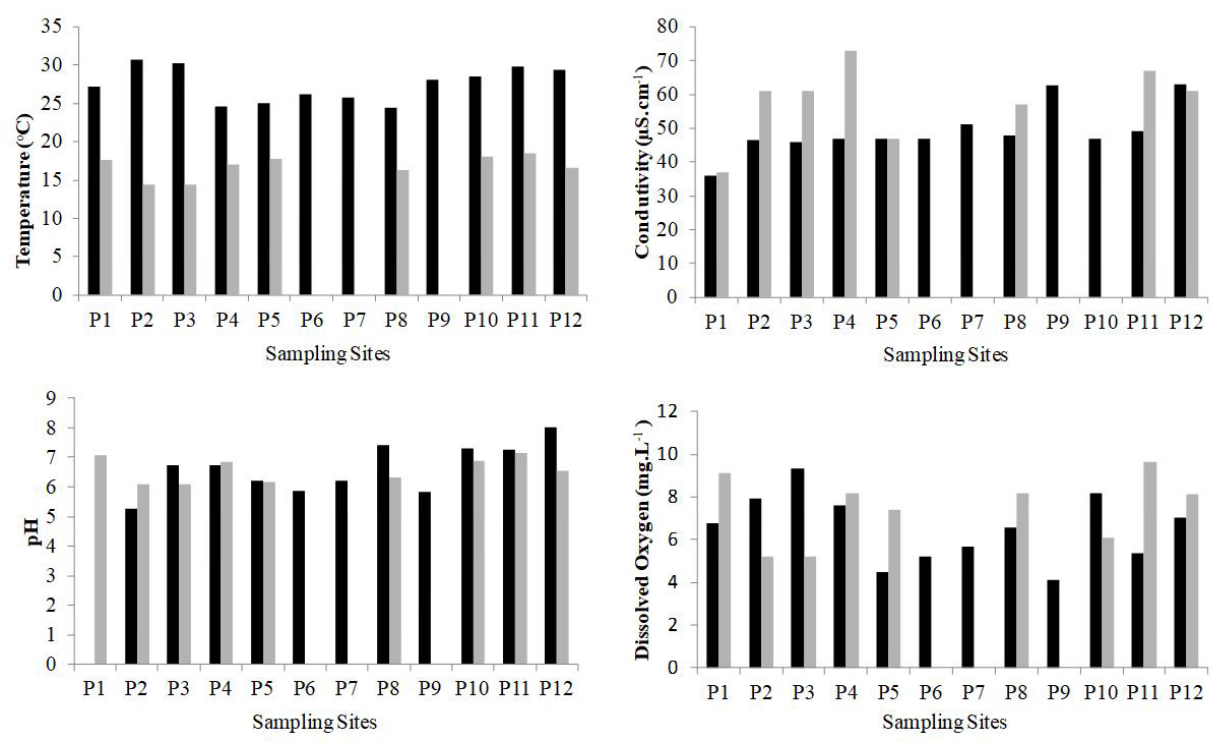

- summer winter

Figure 3. Variation of $\mathrm{pH}$ values, electrical conductivity $\left(\mu \mathrm{cm}^{-1}\right)$, water temperature $\left({ }^{\circ} \mathrm{C}\right)$ and concentration of dissolved oxygen $\left(\mathrm{mg} \mathrm{L}^{-1}\right)$ at different sampling sites of the Itupararanga Reservoir in two seasons (summer and winter) in 2010. There were no measurements in the sampling sites with absence of macrophytes (in the winter P6, P7 and P9). Some values were missed in the summer due to the low accessibility to the sampling sites.

The identification of the macrophyte species showed the occurrence of 10 families, 13 genera and richness of 16 species (Table 1). The emergent species were dominant (12 species), four species were free floating and one species had floating leaves. Due to the absence of reproductive structures, some species could not be identified. Therefore, in the analysis of temporal variation, the species Polygonum lapathifolium, P. puctatum, Alternanthera philoxeroides and Ludwigia longifolia were grouped according to their respective genera.

The highest richness occurred in the summer (15 species - O. cubense was absent) except for P2 and P8 sampling sites mainly due to P. stratiotes and E. crassipes at $\mathrm{P} 2$ and $O$. cubense and Polygonum sp. at P8 sampling sites (Figure 4). In the winter, 10 species were identified (Table 2).

The most common species were Polygonum sp. and Urochloa sp. that were predominant in the summer, occurring at P7 and P8 sampling sites, respectively. At the P11, Polygonum sp. was the predominant species. In the winter, $E$. crassipes was the most representative species, occurring in 5 sampling sites, as well as Urochloa sp. which occurred in 4 sampling sites (Table 2). The mean total biomass of aquatic macrophytes was higher in the winter (573.5 gDM.m ${ }^{-2}$ ) than in the summer $\left(492.8\right.$ gDM.m $\left.{ }^{-2}\right)$ due to high E. crassipes biomass in the winter (1245 gDM.m ${ }^{-2}$ ) (Table 2). However, the differences of the two seasons were not significant $(\mathrm{p}=0.372)$.

Cluster analysis of the floristic composition showed a similarity of 0.367 between three groups in the summer (Group 1: P1, P4, P5, P6, P7, P8; Group 2: P2, P3 and P9; Group 3: P10, P11 and P12) (Figure 5a). In the winter, the sampling sites $\mathrm{P} 1, \mathrm{P} 4, \mathrm{P} 5$ and $\mathrm{P} 8$ including P2 were also clustered (Group 1), as well as P10 and P11 (Group 2) and the third group was formed by P3 and P12 (Figure 5b).

\section{Discussion}

The highest macrophyte richness in the rainy season (summer), mainly for emergent species, corroborates the initial hypothesis. The low variation of biomass for most species in both the summer and winter indicated that the seasonality is not a key factor for most of the macrophyte community development. However, the low similarity suggests that the Itupararanga Reservoir is a heterogeneous ecosystem supporting the growth of different species contributing to biological diversity. Despite the low spatial variation of the physical and chemical variables, some recent studies (Cunha \& Calijuri, 2011b; Bottino et al., 2013) reported that the main factors related to the spatial heterogeneity of 
Table 1. Species checklist, families and life forms of macrophytes from the Itupararanga Reservoir in the summer (February, 2010) and in the winter (June, 2010).

\begin{tabular}{|c|c|c|c|}
\hline Clade & Family & Species & Life Form \\
\hline \multicolumn{4}{|c|}{ Pteridophytes } \\
\hline \multicolumn{4}{|c|}{ Salviniaceae } \\
\hline & & Salvinia sp. & $\mathrm{FF}$ \\
\hline \multicolumn{4}{|c|}{ Angiosperms } \\
\hline \multicolumn{4}{|c|}{ Clade Anita } \\
\hline \multicolumn{4}{|c|}{ Nymphaeaceae } \\
\hline & & Nymphaea sp. & $\mathrm{FL}$ \\
\hline \multicolumn{4}{|c|}{ Clade Monocotyledons } \\
\hline \multicolumn{4}{|c|}{ Araceae } \\
\hline & & Pistia stratiotes $L$. & $\mathrm{FF}$ \\
\hline \multicolumn{4}{|c|}{ Cyperaceae } \\
\hline & & Cyperus giganteus Vahl. & EM \\
\hline & & Cyperus mundtii (Nees) Kunth & EM \\
\hline & & Oxycaryum cubense (Poepp. \& Kunth) Lye & EM \\
\hline \multicolumn{4}{|c|}{ 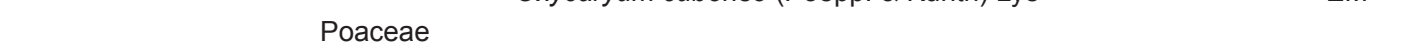 } \\
\hline & & Hymenachne pernambucensis (Spreng.) Zuloaga & EM \\
\hline & & Urochloa sp. & EM \\
\hline \multicolumn{4}{|c|}{ Pontederiaceae } \\
\hline & & Eichhornia crassipes (Mart.) Solms. & FF \\
\hline & & Eichhornia azurea (Sw.) Kunth & EM \\
\hline & & Pontederia cordata L. & EM \\
\hline \multicolumn{4}{|c|}{ Clade Eudicots } \\
\hline \multicolumn{4}{|c|}{ Rosids } \\
\hline \multicolumn{4}{|c|}{ Haloragaceae } \\
\hline & & Myriophyllum aquaticum (Vell.) Verdc. & EM \\
\hline \multicolumn{4}{|c|}{ Onagraceae } \\
\hline & & Ludwigia longifolia (DC.) H.Hara longfolia & EM \\
\hline \multicolumn{4}{|c|}{ Polygonaceae } \\
\hline & & Polygonum punctatum Elliott & EM \\
\hline & & Polygonum lapathifolium L. & EM \\
\hline \multicolumn{4}{|c|}{ Asterids } \\
\hline \multicolumn{4}{|c|}{ Amaranthaceae } \\
\hline & & Alternanthera philoxeroides (Mart.) Griseb. & EM \\
\hline
\end{tabular}

EM: Emergent; FF: Free Floating; FL: Floating Leaves.

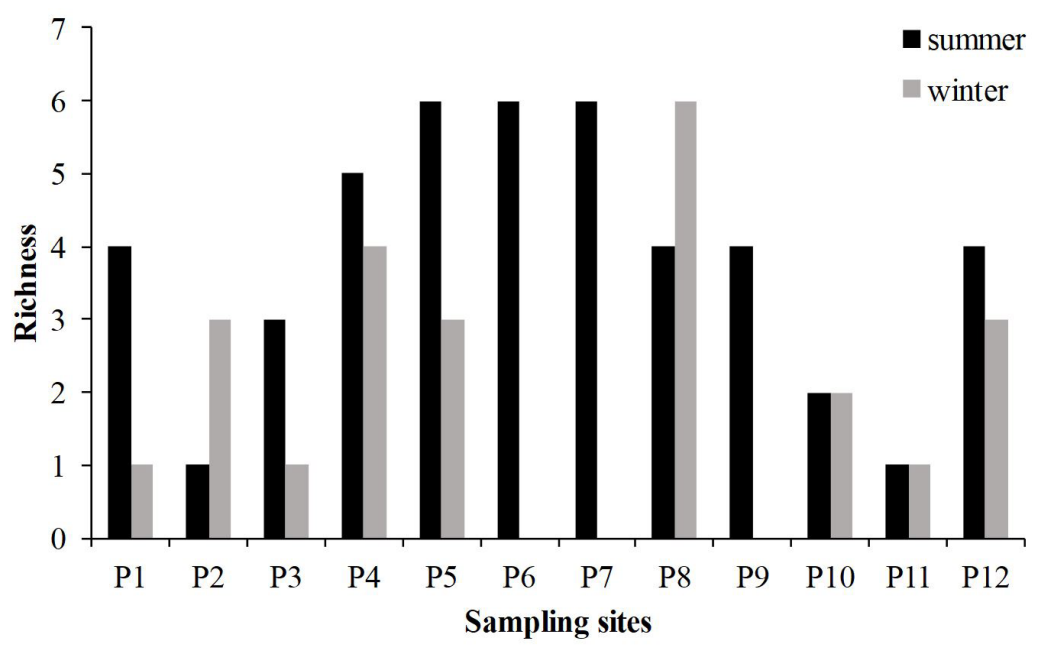

Figure 4. Macrophyte species richness in different sampling sites of the Itupararanga Reservoir during two periods (summer and winter). 
Table 2. Occurrence of aquatic macrophytes species in the different sampling sites from Itupararanga Reservoir and their total biomass in the summer (February, 2010) and in the winter (June, 2010). The $t$ test was not performed on the species occurring in only one period and to Pistia stratiotes due to the low abundance in the winter.

\begin{tabular}{|c|c|c|c|c|}
\hline \multirow{2}{*}{ Species } & \multicolumn{2}{|c|}{ Total Biomass (gDM.m²) } & \multicolumn{2}{|c|}{ Sampling Site } \\
\hline & Summer & Winter & Summer & Winter \\
\hline Salvinia sp. & $0.29 \pm 0.34 \mathrm{~b}$ & $53.7 \pm 11.43 \mathrm{a}$ & P4, P7, P8 & P4, P5, P8 \\
\hline Nymphaea sp. & - & - & P10 & P10 \\
\hline Pistia stratiotes & $117.2 \pm 76.46$ & $6.4 \pm 6.76$ & P4, P6, P7, P8 & P2, P4, P8 \\
\hline Cyperus giganteus & - & - & P7 & - \\
\hline Cyperus mundtii & $107.94 \pm 204.83$ & - & P5, P6 & - \\
\hline Oxycaryum cubense & - & $4.32 \pm 8.65$ & - & P8 \\
\hline Hymenachne pernambucensis & $55.03 \pm 110.06$ & - & P7 & - \\
\hline Urochloa sp. & $488.2 \pm 149.91 \mathrm{a}$ & $130.4 \pm 170.59 \mathrm{~b}$ & $\begin{array}{c}\text { P1, P2, P3, P4, P5, } \\
\text { P6, P8, P9 }\end{array}$ & $\mathrm{P} 2, \mathrm{P} 4, \mathrm{P} 5, \mathrm{P} 8$ \\
\hline Eichhornia crassipes & $568.5 \pm 415.25 b$ & $1245 \pm 338.52 \mathrm{a}$ & $\begin{array}{c}\mathrm{P} 1, \mathrm{P} 4, \mathrm{P} 5, \mathrm{P} 7, \mathrm{P} 8 \\
\mathrm{P} 12\end{array}$ & P2, P4, P5, P8, P12 \\
\hline Eichhornia azurea & $97.7 \pm 121.43 a$ & $42.4 \pm 84.75 \mathrm{a}$ & P12 & P12 \\
\hline Pontederia cordata & $44.42 \pm 88.84$ & - & P5 & - \\
\hline Myriophyllum aquaticum & $147.5 \pm 294.9 \mathrm{a}$ & $102 \pm 76.46 a$ & P5, P6, P7, P9, P12 & P3, P12 \\
\hline Ludwigia sp. & $71.6 \pm 141.03 \mathrm{a}$ & $215 \pm 126.69 a$ & $\mathrm{P} 1, \mathrm{P} 4, \mathrm{P} 5, \mathrm{P} 6, \mathrm{P} 9$ & P1 \\
\hline Polygonum sp. & $750 \pm 387.39$ a & $750.3 \pm 129.34 a$ & $\begin{array}{l}\mathrm{P} 1, \mathrm{P} 3, \mathrm{P} 6, \mathrm{P} 9 \\
\mathrm{P} 10, \mathrm{P} 11, \mathrm{P} 12\end{array}$ & P8, P10, P11 \\
\hline Alternanthera philoxeroides & $20.58 \pm 41.16$ & - & P3 & - \\
\hline Total Mean & $492.8 \pm 255.42$ & $573.5 \pm 434.17$ & & \\
\hline
\end{tabular}

Values not obtained (-). Different letters indicate significant differences between the two periods.

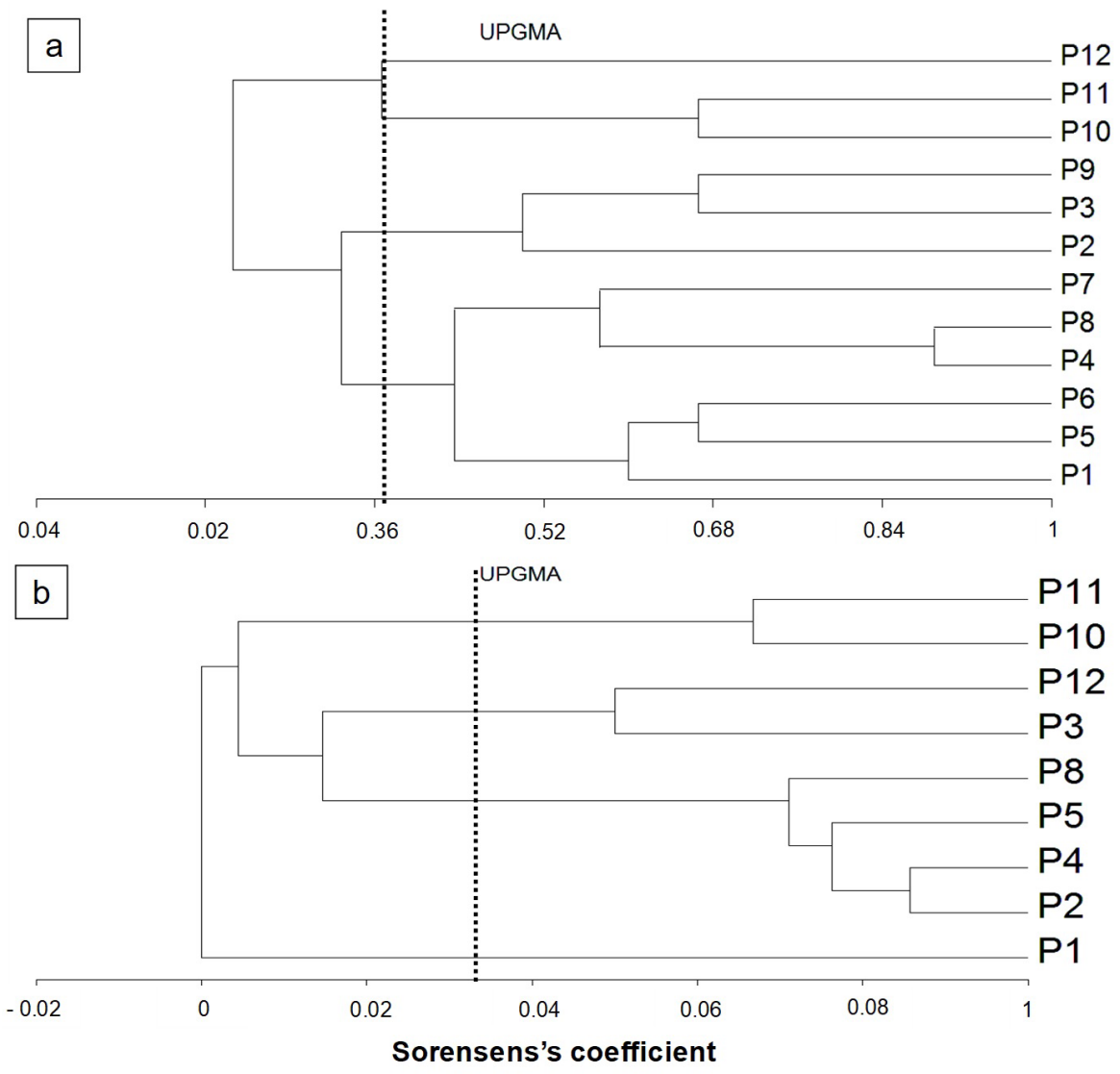

Figure 5. Cluster analysis of floristic similarity of the sampling stations of the Itupararanga Reservoir in two seasons (a: summer; b: winter). 
the littoral area of the Itupararanga Reservoir are dissolved nutrients and sediment composition.

The regularization of water flow did not alter the mean water level of the reservoir despite high rainfall in the summer. Therefore, the reservoir exhibits a low variation in the water level throughout the year maintaining a low depth even in the rainy season. Low water level, shallow depths and consequently the variation in margin availability (Thomaz \& Bini, 2003; Chen et al., 2015) are characteristics that favor the establishment of aquatic macrophytes, especially emergent species, as found in our study $75 \%$ of species are emegent).

Despite the predominance of emergent species, E. crassipes showed the highest biomass in the winter. Considering that an increase in nutrients is common during this period in the study area (Cunha \& Calijuri, 2011b) and that the electrical conductivity may be considered an indirect measure of the concentrations of nutrients dissolved in the water (Cometti et al., 2008), an increase in this variable in the winter allowed us to suppose that the trophic status influenced the biomass of E. crassipes in the winter.

The occurrence of $E$. crassipes is closely related to the trophic status of the aquatic ecosystem (Hoveka et al., 2016; Lacoul \& Freedman, 2006) and the occurrence of this plant, mainly in the most eutrophic riverine zone, which corroborates our statement and suggests that the lower flow of the rivers in the winter favors the establishment and development of the floating species.

The macrophyte species composition in the Tietê River Basin (Carvalho et al., 2003; Cavenaghi et al., 2003; Martins et al., 2008; Smith et al., 2014; Tanaka et al., 2002) is similar to those found in the Itupararaga Reservoir. In this ecosystem, there was a predominance of emergent species (Polygonum lapathifolium, Althernanthera philoxeroides, Eichhornia azurea) and others such as Myriophyllum aquaticum, Pistia stratiotes, Eichhornia crassipes and Salvinia, Hymenachne, Ludwigia, Cyperus and the Nymphaea genus. It suggests species dispersion through the catchment and also that the rainy season increases the probability of transporting these plants and improves their growth due to the high temperature and photoperiod of the summer.

The wide occurrence and the high biomass of Urochloa sp. is a concern for the Itupararanga Reservoir, as this species is an invasive grass and the knowledge about its management is scarce. In Brazil, the main studies related to the biological invasion of Urochloa sp. were carried out in the Paraná
River Basin, specifically in the Itaipú Reservoir (Michelan et al., 2010; Thomaz \& Michelan, 2011) using the Urochloa arrecta (Trin.) R. D. Webster grass. This Poaceae from Africa is widely distributed in Brazil and has a high invasive potential affecting the distribution of native species in both natural and man-made ecosystems due to its high regeneration capacity after disturbances, including regeneration by rhizomes and/or seeds, high growth rate and efficient dispersion strategy (Michelan et al., 2013).

In general, most of the sites with a presence of macrophytes were close to the areas with anthropogenic influence, in the form of small urban centers or farms. As a consequence, the input of nutrients in these areas is higher, supporting eutrophication in some periods of the year (Cunha \& Calijuri, 2011a). Anthropic activities favor the macrophyte growth, mainly of emergent species (Del Pozo et al., 2011; Biudes \& Camargo, 2006). The right margin of the Itupararanga Reservoir has a conserved PPA (Permanent Protection Area), which probably maintains the water quality in a better condition than in other areas of the reservoir. In addition, the microclimate (e.g. low temperatures of water - personal observation) and low light intensity of this bank due to the preservation of the forest may reduce the occurrence of macrophytes.

The selection of sampling sites for this study revealed that macrophytes occurring on the left margin of the Itupararanga Reservoir denoting human activities (e.g. agriculture, urban development and domestic sewage input) influence the development of aquatic plants, which are mainly emergent and floating. Our research showed that the highest richness occurred in the summer with a predominance of emerging species that had low seasonal variation of biomass (eg, Polygonum sp.). However, the total biomass was high in the winter mainly due to the growth of free-floating species (e.g. E. crassipes) that increase their potential growth in the low flow periods. The nuisance species Urochloa sp. decreased its biomass significantly between the two periods, but was present in $66 \%$ of the sampling sites in the summer and up to $40 \%$ in the winter. The physical and chemical variables showed no spatial variation, but the sampling sites near to the headwater were clustered suggesting the eutrophication of this regions plays an important role in the water quality and species diversity. Continuous monitoring of macrophyte development in the Itupararanga Reservoir is important to maintain multiple uses 
and biodiversity, mainly due to the occurrence of exotic Poaceae species. The Itupararanga Reservoir reflects the species incidence of the catchment and its increasing eutrophication may have implications for the species exportation to a reservoir chain in the Tietê River Basin.

\section{Acknowledgements}

We would like to thank Coordenadoria de Aperfeiçoamento de Pessoal de nível Superior (CAPES) and Fundação de Amparo à Pesquisa do Estado de São Paulo (FAPESP - Process no 2008/55636-9) for funding this research.

\section{References}

AMARAL, M.C.E., BITTRICH, V., FARIA, A.D., ANDERSON, L.O. and AONA, L.Y.S. Guia para plantas aquáticas e palustres do estado de São Paulo. Ribeirão Preto: Holos, 2008.

BAKKER, E.S., SARNEEL, J.M., GULATI, R.D., LIU, Z. and VAN DONK, E. Restoring macrophyte diversity in shallow temperate lakes: biotic versus abiotic constraints. Hydrobiologia, 2012, 710(1), 23 37. http://dx.doi.org/10.1007/s10750-012-1142-9.

BEGHELLI, F.G.S., SANTOS, A.C.A., URSOGUIMARÁES, M.V. and CALIJURI, M.C. Spatial and temporal heterogeneity in a subtropical reservoir and their effects over the benthic macroinvertebrate community. Acta Limnologica Brasiliensia, 2014, 26(3), 306-317. http://dx.doi.org/10.1590/S2179975X2014000300010.

BIUDES, J.F.V. and CAMARGO, A.F.M. Changes in biomass, chemical composition and nutritive value of Spartina alterniflora due to organic pollution in the Itanhaém River Basin (SP, Brazil). Brazilian Journal of Biology = Revista Brasileira de Biologia, 2006, 66(3), 781-789. PMid:17119825. http://dx.doi. org/10.1590/S1519-69842006000500003.

BOTTINO, F., CALIJURI, M.D.C. and MURPHY, K.J. Temporal and spatial variation of limnological variables and biomass of different macrophyte species in a Neotropical reservoir (Sáo Paulo - Brazil). Acta Limnologica Brasiliensia, 2013, 25(4), 387-397. http://dx.doi.org/10.1590/S2179975X2013000400004.

CARVALHO, F.T., GALO, M.L.B.T., VELINI, E.D. and MARTINS, D. Plantas aquáticas e nível de infestação das espécies presentes no reservatório de Barra Bonita, no rio Tietê. Planta Daninha, 2003, 21(spe), 15-19. http://dx.doi.org/10.1590/S010083582003000400003.

CAVENAGHI, A.L., VELINI, E.D., GALO, M.L.B.T., CARVALHO, F.T., NEGRISOLI, E., TRINDADE, M.L.B. and SIMIONATO, J.L.A. Caracterização da qualidade de água e sedimento relacionados com a ocorrência de plantas aquáticas em cinco reservatórios da bacia do rio Tietê. Planta Daninha, 2003, 21(spe), 43-52. http://dx.doi.org/10.1590/ S0100-83582003000400007.

CHAMBERS, P.A., LACOUL, P., MURPHY, K.J. and THOMAZ, S.M. Global diversity of aquatic macrophytes in freshwater. Hydrobiologia, 2007, 595(1), 9-26. http://dx.doi.org/10.1007/s10750007-9154-6.

CHEN, X.-S., DENG, Z.-M., XIE, Y.-H., LI, F., HOU, Z.-Y. and LI, X. Belowground bud banks of four dominant macrophytes along a small-scale elevational gradient in Dongting Lake wetlands, China. Aquatic Botany, 2015, 122, 9-14. http:// dx.doi.org/10.1016/j.aquabot.2014.12.006.

CHOI, J.-Y., JEONG, K.-S., LA, G.-H. and JOO, G.$\mathrm{J}$. Effect of removal of free-floating macrophytes on zooplankton habitat in shallow wetland. Knowledge and Management of Aquatic Ecosystems, 2014, 414(414), 11p1-11p10. http://dx.doi.org/10.1051/ $\mathrm{kmae} / 2014023$.

COMETTI, N.N., MATIAS, G.C.S., ZONTA, E., MARY, W. and FERNANDES, M.S. Efeito da concentração da solução nutritiva no crescimento da alface em cultivo hidropônico - sistema NFT. Horticultura Brasileira, 2008, 26(2), 252-257. http:// dx.doi.org/10.1590/S0102-05362008000200027.

COMPANHIA AMBIENTAL DO ESTADO DE SÃO PAULO - CETESB. Relatório de Qualidade das águas Interiores do Estado de São Paulo. São Paulo: CETESB, 2012.

COMPANHIA AMBIENTAL DO ESTADO DE SÃO PAULO - CETESB. Relatório de Qualidade das águas Interiores do Estado de São Paulo. São Paulo: CETESB, 2016.

CUNHA, D.G.F. and CALIJURI, M.C. Limiting factors for phytoplankton growth in subtropical reservoirs: the effect of light and nutrient availability in different longitudinal compartments. Lake and Reservoir Management, 2011a, 27(2), 162-172. http://dx.doi. org/10.1080/07438141.2011.574974.

CUNHA, D.G.F. and CALIJURI, M.C. Variação sazonal dos grupos funcionais fitoplanctônicos em braços de um reservatório tropical de usos múltiplos no estado de São Paulo (Brasil). Acta Botanica Brasilica, 2011b, 25(4), 822-831. http://dx.doi.org/10.1590/S010233062011000400009.

DEL POZO, R., FERNÁNDEZ-ALÁEZ, C. and FERNÁNDEZ-ALÁEZ, M. The relative importance of natural and anthropogenic effects on community composition of aquatic macrophytes in Mediterranean ponds. Marine \& Freshwater Research, 2011, 62(2), 101-109. 
GARCIA, J.P.M., FREITAS, N.P. and SILVA FILHO, N.L. Caracterização geo-ambiental da Represa de Itupararanga [online]. 1999 [viewed 9 Mar. 2016]. Rio Claro: IBRC-UNESP. Available from: http:// IPE.ibrc.unesp.br/cbhsmt/projeto.html

HOLMROOS, H., HORPPILA, J., NIEMISTÖ, J., NURMINEN, L. and HIETANEN, S. Dynamics of dissolved nutrients among different macrophyte stands in a shallow lake. Limnology, 2015, 16(1), 3139. http://dx.doi.org/10.1007/s10201-014-0438-z.

HOVEKA, L.N., BEZENG, B.S., YESSOUFOU, K., BOATWRIGHT, J.S. and VAN DER BANK, M. Effects of climate change on the future distributions of the top five freshwater invasive plants in South Africa. South African Journal of Botany, 2016, 102, 3338. http://dx.doi.org/10.1016/j.sajb.2015.07.017.

INSTITUTO DE PESQUISAS JARDIM BOTÂNICO DO RIO DE JANEIRO. Flora do brasil $2020 \mathrm{~cm}$ construção [online]. Rio de Janeiro: COPPETECUFRJ, 2016 [viewed 9 Mar. 2016]. Available from: http://floradobrasil.jbrj.gov.br/

JONIAK, T., KUCZYŃSKA-KIPPEN, N. and NAGENGAST, B. The role of aquatic macrophytes in microhabitatual transformation of physicalchemical features of small water bodies. Hydrobiologia, 2007, 584(1), 101-109. http://dx.doi.org/10.1007/ s10750-007-0595-8.

KENNEDY, M.P., LANG, P., GRIMALDO, J.T., MARTINS, S.V., BRUCE, A., HASTIE, A., LOWE, S., ALI, M.M., SICHINGABULA, H., DALLAS, H., BRIGGS, J. and MURPHY, K.J. Environmental drivers of aquatic macrophyte communities in southern tropical African rivers: Zambia as a case study. Aquatic Botany, 2015, 124, 19-28. http:// dx.doi.org/10.1016/j.aquabot.2015.03.002.

KOVALENKO, K.E., DIBBLE, E.D., AGOSTINHO, A.A., CANTANHÊDE, G. and FUGI, R. Direct and indirect effects of an introduced piscivore, Cichla kelberi and their modification by aquatic plants. Hydrobiologia, 2009, 638(1), 245-253. http://dx.doi. org/10.1007/s10750-009-0049-6.

LACOUL, P. and FREEDMAN, B. Environmental influences on aquatic plants in freshwater ecosystems. Environmental Reviews, 2006, 14(2), 89-136. http:// dx.doi.org/10.1139/a06-001.

MARTINS, D., COSTA, N.V., TERRA, M.A. and MARCHI, S.R. Caracterização da comunidade de plantas aquáticas de dezoito reservatórios pertencentes a cinco bacias hidrográficas do Estado de São Paulo. Planta Daninha, 2008, 26(1), 17-32. http://dx.doi. org/10.1590/S0100-83582008000100003.

MICHELAN, T.S., THOMAZ, S.M. and BINI, L.M. Native Macrophyte density and richness affect the invasiveness of a Tropical Poaceae Species. PLoS One, 2013, 8(3), e60004. PMid:23536902. http://dx.doi. org/10.1371/journal.pone.0060004.
MICHELAN, T.S., THOMAZ, S.M., MORMUL, R.P. and CARVALHO, P. Effects of an exotic invasive macrophyte (tropical signalgrass) on native plant community composition, species richness and functional diversity. Freshwater Biology, 2010, 55(6), 1315-1326. http://dx.doi.org/10.1111/j.13652427.2009.02355.x.

PADIAL, A.A., THOMAZ, S.M. and AGOSTINHO, A.A. Effects of structural heterogeneity provided by the floating macrophyte Eichhornia azurea on the predation efficiency and habitat use of the small Neotropical fish Moenkhausia sanctaefilomenae. Hydrobiologia, 2009, 624(1), 161-170. http://dx.doi. org/10.1007/s10750-008-9690-8.

PIETERSE, A.H. and MURPHY, K.J. Aquatic weeds: the ecology and management of nuisance aquatic vegetation. Oxford: Oxford University Press, 1993.

PITELLI, R.L.C.M., TOFFANELI, C.M., VIEIRA, E.A., PITELLI, R.A. and VELINI, E.D. Dinâmica da comunidade de macrófitas aquáticas no reservatório de Santana, RJ. Planta Daninha, 2008, 26(3), 473-480. http://dx.doi.org/10.1590/S010083582008000300001 .

POMPÊO, M.L.M. and MOSCHINI-CARLOS, V. Macrófitas aquáticas e perifiton: aspectos ecológicos e metodológicos. São Carlos: RiMa, 2003.

POTT, V.J. and POTT, A. Plantas aquáticas do Pantanal. Brasília: Embrapa Comunicação para Transferência de Tecnologia, 2000.

SCREMIN-DIAS, E. Nosjardins submersos da Bodoquena: guia para identificação de plantas aquáticas de Bonito e região. Campo Grande: ECOA-Ecologia e Ação, 1999.

SMITH, W.S., ESPÍNDOLA, E.L.G. and ROCHA, O. Environmental gradient in reservoirs of the medium and low Tietê River: limnological differences through the habitat sequence. Acta Limnologica Brasiliensia, 2014, 26(1), 73-88. http://dx.doi.org/10.1590/ S2179-975X2014000100009.

SOARES, M.C.S., MARINHO, M.M., HUSZAR, V.L.M., BRANCO, C.W.C. and AZEVEDO, S.M.F.O. The effects of water retention time and watershed features on the limnology of two tropical reservoirs in Brazil. Lakes and Reservoirs: Research and Management, 2008, 13(4), 257-269. http://dx.doi. org/10.1111/j.1440-1770.2008.00379.x.

TANAKA, R.H., CARDOSO, L.R., MARTINS, D., MARCONDES, D.A.S. and MUSTAFÁ, A.L. Ocorrência de plantas aquáticas nos reservatórios da Companhia Energética de São Paulo. Planta Daninha, 2002, 20(spe), 101-111. http://dx.doi. org/10.1590/S0100-83582002000400012.

THOMAZ, S.M. and BINI, L.M. Ecologia e manejo de macrófitas aquáticas. Maringá: Eduem, 2003, 341 p.

THOMAZ, S.M. and MICHELAN, T.S. Associations between a highly invasive species and native macrophytes differ across spatial scales. Biological 
Invasions, 2011, 13(8), 1881-1891. http://dx.doi. org/10.1007/s10530-011-0008-9.

VALENTIN, J.L. Ecologia numérica: uma introdução à análise multivariada de dados ecológicos. Rio de Janeiro: Interciência, 2000.

WESTLAKE, D.F. Some basic investigation of the productivity of aquatic macrophytes. Memorie dell'Istituto Italiano di Idrobiologia, 1965, 18, 229-248.
ZIEGLER, J.P., SOLOMON, C.T., FINNEY, B.P. and GREGORY-EAVES, I. Macrophyte biomass predicts food chain length in shallow lakes. Ecosphere, 2015, 6(1), 1-16. http://dx.doi.org/10.1890/ES1400158.1.

Received: 26 October 2016

Accepted: 18 July 2017 